\title{
Intra-aortic Balloon Pumping
}

Citation for published version (APA):

Lozekoot, P. (2019). Intra-aortic Balloon Pumping: new insights for an old therapy. [Doctoral Thesis, Maastricht University]. ProefschriftMaken Maastricht. https://doi.org/10.26481/dis.20190215pl

Document status and date:

Published: 01/01/2019

DOI:

10.26481/dis.20190215pl

Document Version:

Publisher's PDF, also known as Version of record

\section{Please check the document version of this publication:}

- A submitted manuscript is the version of the article upon submission and before peer-review. There can be important differences between the submitted version and the official published version of record.

People interested in the research are advised to contact the author for the final version of the publication, or visit the DOI to the publisher's website.

- The final author version and the galley proof are versions of the publication after peer review.

- The final published version features the final layout of the paper including the volume, issue and page numbers.

Link to publication

\footnotetext{
General rights rights.

- You may freely distribute the URL identifying the publication in the public portal. please follow below link for the End User Agreement:

www.umlib.nl/taverne-license

Take down policy

If you believe that this document breaches copyright please contact us at:

repository@maastrichtuniversity.nl

providing details and we will investigate your claim.
}

Copyright and moral rights for the publications made accessible in the public portal are retained by the authors and/or other copyright owners and it is a condition of accessing publications that users recognise and abide by the legal requirements associated with these

- Users may download and print one copy of any publication from the public portal for the purpose of private study or research.

- You may not further distribute the material or use it for any profit-making activity or commercial gain

If the publication is distributed under the terms of Article $25 \mathrm{fa}$ of the Dutch Copyright Act, indicated by the "Taverne" license above, 
Summary 

This thesis studies the effects of intra-aortic balloon counter-pulsation (IABP) treatment on the visceral arterial circulation, together with an evaluation of the optimal weaning strategy from this hemodynamic mechanical support modality.

IABP treatment in its current form has been used in the clinical setting for decades, but despite the long experience of the cardiovascular society with this therapy, IABP is still associated with a significant complication rate. One of the potential lethal complications of IABP treatment is visceral ischemia, potentially due to obstructive or non-obstructive positioning of the IABP-catheter. In this thesis, we further elucidated the effect of optimal positioned intra-aortic balloon (IAB) on visceral arterial flows and its potential for optimization of IABP catheter use and design in a porcine model.

The general background and introduction to the studies presented in this thesis are provided in Chapter 1.

In Chapter $\mathbf{2}$ we have explored the arterial waveform patterns in the visceral circulation during IABP support. In an animal study, we found that the wave patterns in both the mesenteric and the renal arterial vasculature, although to a lesser extent, are altered due to IABP therapy. The wave pattern in the superior mesenteric artery (SMA) showed an immediate drop in arterial flow during early and mid-diastole, while there was a sudden rise in flow in late diastole. In the systolic phase the flow increased again, but remained lower than baseline. We postulated that the origin of these effects are threefold: 1) a direct intrinsic (myotonic) negative feedback mechanism of the smooth muscle cells in the wall of the SMA leading to vasoconstriction following the rise in vascular pressure due to balloon inflation; 2) an increase in baroreceptor response due a diphasic output wave following diastolic balloon augmentation; 3) a reversal of energy stored in the elastic aortic wall following balloon inflation in diastole leading to an increase in SMA flow in late diastole. When studying both left and right renal flows, it was observed that flows in both arteries were similar during all phases of IABP support. However, the arterial flow in early diastole was not altered, but decreased significantly in mid diastole, followed by a significant late diastolic increase ending with a non-significant increase during systole. Although an alteration in baroreceptor response and a reversal of energy stored in the arterial vascular wall could also be applicable for the renal situation, theoretically there could not have been any local autoregulatory influence at the renal arterial vasculature since mean arterial pressures were kept above its lower tress hold level of $60 \mathrm{mmHg}$. Following the observations made in this chapter, there might be room for new triplesegmented and dual-chambered new balloons. These catheters have been designed in the past, but never found the way to the clinical setting. This study thus advocates for a renewed discussion about the necessity for new IAB designs.

Chapter $\mathbf{3}$ gave us more insight in the effect of variable balloon volumes on IABP performance. The optimal weaning strategy (i.e. a volume-based weaning strategy or a rate-based weaning strategy) still remains subject of discussion. Therefore, animal 
experiments were performed, comparing these two different IABP weaning strategies. Weaning by progressive volume deflation showed significant hemodynamic effects: a greater degree of vasodilation, better cardiac output and stroke volume, less negative values of cardiac cycle efficiency, and a higher $\mathrm{dP} / \mathrm{dT} \max$ compared with those weaned by rate-reduction. Furthermore, volume based weaning exhibited increased coronary flow, lower oxygen consumption of the myocardium, a lower coronary resistance and lower serum lactate levels.

Our findings thus suggest that a volume-based weaning strategy is thus preferable, leading to hemodynamic, coronary and metabolic advantages.

Malpositioning of IABP is a common cause of visceral artery compromise, potentially leading to occlusive mesenteric ischemia. However, even when positioned correctly, strictly adhering to manufacturer's implantation protocols, conventional intra-aortic balloons will lead to a so-called anatomic-to-device mismatch in $70 \%$ of patients treated as observed on CT-scans. Shorter balloons might thus be beneficial. In Chapter $\mathbf{4}$ to $\mathbf{7}$ we dove into the concept of shorter-sized IABP and balloon volumes using four different balloon catheters (Zeon Medical Inc., Tokyo, Japan) in a porcine model of ischemiareperfusion. The used catheters were a two conventional 'longer' 35- and 40-mL catheters, together with a yet clinically available $40-\mathrm{mL}$ and a prototype $35-\mathrm{mL}$ 'short' catheter.

In Chapter 4, we described a proof-of-principle study evaluating two new short-sized IAB catheters (35-mL and 40-mL) vs. unsupported controls. All animals showed a significant decrease in superior mesenteric artery (SMA), and left and right renal blood flows during 2 hours of myocardial ischemia in comparison with baseline. However, both interventional groups showed a significant improvement in SMA and renal blood flows, remaining constant in comparison with the control group. After 6 hours of reperfusion only the renal blood flows returned to baseline levels, whereas SMA blood flows remained just a fraction lower than baseline. Hemodynamic improvements were observed in both IABP groups following reperfusion in comparison with controls, which also translated in coronary circulatory benefits: reduced coronary vascular resistance and myocardial oxygen demand in conjunction with increased myocardial oxygen supply. Since we used fluoroscopy to guarantee non-occlusive IABP placement, we postulate that these favourable effects are partly due to enhanced vasomotor control effects similarly observed in situations of haemorrhagic shock.

From this proof-of-concept study we learned that a short IABP balloon comes with the well-known beneficial properties of counterpulsation in terms of hemodynamics and coronary circulation, but also enhanced visceral flow as compared to control animals not receiving IABP therapy. Nonetheless, if from one side the shorter balloon length is advantageous in order to prevent visceral ischemia, its hemodynamic and coronary circulatory might be less efficacious due to the shorter length if compared with a normal length balloon catheter. 
Chapter 5 was thus aimed at comparing a short and a standard-sized balloon with same filling volumes $(40 \mathrm{~mL})$ in order to verify the differences regarding visceral flow, coronary circulation and hemodynamic performance during aortic counterpulsation in a porcine model of myocardial ischemia-reperfusion injury. Again, an unsupported control group was added for validation purposes, while fluoroscopy was used to rule out that any observations made during this study were related to an obstructive origin. The SMA blood flow was increased by short IAB therapy and reduced by standard-balloon support, even when indexing for changes in mean arterial pressure, mean vascular resistances and cardiac output. From a mechanical viewpoint, we hypothesized that the standard-sized balloons, being longer and ending closer to the ostium of the SMA, create a more turbulent flow at the ostium of the SMA. Given the fact that a non-laminar blood stream increases the perfusion pressure required to drive a given flow, it is possible that even at comparable perfusion pressures, intra-aortic turbulence, induced by the presence of a standard IABP balloon close to the vessel orifice, would lead to a decrease in flow. Another explanation for this finding, could be that, the greater expansion of the short balloon due to its larger diameter, might translate into a greater energy stored in the elastic tissues of the aorta, and transmitted back to the column of blood interposed between the arterial wall and the balloon surface. Finally, we postulated that the height of the blood column comprised between the balloon's tip and the SMA ostium in the short balloon is larger, leading to greater perfusion pressure and, consequently, higher SMA blood flows. From a neuro-endocrine standpoint it could be hypothesized that activation of aortic baro-receptors inhibiting the medullary vasoconstrictor reflex and a higher arterio-venous gradient, both due to increased diastolic blood pressures, contribute to this finding. Renal blood flows increased during IABP treatment in both standard-sized and short-balloon subjects, but these improvements were significantly higher in short balloon subjects in comparison with the standard-sized balloons. This could be explained by similar mechanical explanations as given for SMA flows. Given the beneficial effects of the short balloon on the visceral circulation, we found that these favourable effects were not at expense of hemodynamic or coronary performances. The short balloon showed comparable result to the standard-sized balloon in terms of cardiac output, systemic vascular resistance and $\mathrm{dp} / \mathrm{d} \mathrm{T}_{\max }$ cardiac cycle efficiency throughout the experiment. Furthermore, the short balloon reduced the myocardial vascular resistance and myocardial oxygen consumption, while at the same time increasing, coronary blood flow with no difference with the standard balloons. This was likely to be related to the balloon volume and, therefore, to the same amount of blood volume displaced by the two different balloons, resulting in comparable diastolic pressure augmentation. Concluding: shorter-sized IAB-catheters with similar volumes might create less visceral perfusion disturbances, while maintaining classic IABP supportive effects.

In Chapter 6 we have investigated whether the prototype $35-\mathrm{mL}$ short IAB could be a suitable option for non-small sized patients, potentially reducing the occurrence of in- 
hospital complications related to the balloon size. Therefore, we compared the effects of a prototype $35-\mathrm{mL}$ short IAB with a conventional length $40-\mathrm{mL} I A B$. In this chapter we aimed at demonstrating not only that the prototype $35-\mathrm{mL}$ balloon does not impair visceral circulation, but compared to the standard-sized higher volume (40 mL) IAB balloon, it does not lose its hemodynamic augmentation benefits. The use of a $35-\mathrm{mL}$ short balloon was associated with a significant improvement in visceral flows. The animals allocated to the 35-mL short balloon group showed a significant increase in SMA flows, while a standard $40-\mathrm{mL} I A B$ catheter was associated with a significant decrease in SMA flows. After reperfusion the renal flows increased in both studied groups, although this was to a significantly greater extent in the $35-\mathrm{mL}$ short IABP balloon. Since both $35-\mathrm{ml}$ short and 40-ml short balloons differ only $11 \mathrm{~mm}$ in length and $0.4 \mathrm{~mm}$ in diameter, similar mechanical and neuro-endocrine explanations as proposed in chapter 4 can account for these effects.

Interestingly the hemodynamic and coronary performance of this shorter, less voluminous balloon showed comparable results in comparison with the standard-sized balloons as reflected in cardiac output, systemic vascular resistance, dp/dTmax, coronary blood flows and myocardial oxygen consumption. Beforehand, the 40-mL-standard-sized $I A B$ catheter would be expected to result in greater diastolic pressure augmentation because it is likely to move a greater amount of blood volume. We hypothesized that the greater expansion of the short balloon, because of its larger diameter (17.1 mm vs 15.1 $\mathrm{mm}$ in the $40-\mathrm{mL}$ standard balloon), might translate into a greater energy stored in the elastic tissues of the aorta and transmitted back to the column of blood interposed between the arterial wall and the balloon surface, which needs to be further elucidated in future in-vitro studies.

While we found that there were no significant differences in the hemodynamic and coronary performance of the prototype $35-\mathrm{mL}$ short balloon vs. the conventional $40-\mathrm{mL}$ IAB balloon in chapter 6, questions arose about the potential of the currently to the market available $35-\mathrm{mL}$ long catheter. Although this catheter comes with a substantial shorter balloon in comparison with its $40-\mathrm{ml}$ equivalent ( $214 \mathrm{~mm}$ vs. $243 \mathrm{~mm}$ ) the diameter of this balloon is similar $(15.1 \mathrm{~mL})$. In comparison with the shorter catheters (35-mL: $162 \mathrm{~mm}$ vs. 40-mL: $173 \mathrm{~mm}$ ) they are still considerably longer. Therefore, we studied the effect of this slightly shorter $35-\mathrm{mL}$ conventional IABP balloon on the visceral circulation in comparison with the 35- $\mathrm{ml}$ short, 40-ml short and 40-ml long IABP catheters in a similar model of ischemia-reperfusion in Chapter 7.

During the reperfusion phase we found that the use of a 35- $\mathrm{ml}$ long balloon catheter, although being $29 \mathrm{~mm}$ shorter than its 40-mL equivalents, did not allow any increase in SMA flows throughout the whole experiment even when indexed for alterations in cardiac output, blood pressures or vascular resistances and thus shared similar behaviour as the 40-mL long IABP catheter. The $29 \mathrm{~mm}$ difference in length might theoretically still be insufficient to result in a return of laminar blood flow at the origin of the SMA, as 
proposed in chapter 5, but requires further in-vitro testing. Again, similar to the observations made in chapter 5, renal flows increased during the course of IABP therapy, but again showed to increase to a greater extent in the short-balloon groups in comparison with the longer ones. Since the mean arterial pressures remained stable above the minimum level necessary for the autoregulatory mechanisms of the kidney throughout the whole experiment, these observations regarding renal flows are most likely explained to be due to mechanical IABP effects. Furthermore, there were no significant intra-group differences observed in either the standard-sized or short balloongroups, giving rise to the idea that either the shorter length of the shorter balloon catheters or the increased diameters determine the increase in renal flows, which could be subject to further research. The $35-\mathrm{mL}$ long balloon improved hemodynamics and use of such showed beneficiary effects for the coronary circulation to a similar extent as the shorter and larger-volume balloons. Therefore, from this chapter we conclude that changes in visceral perfusion during IABP support are significantly related to balloon length and not to a small $(5 c c)$ change in volume.

Finally, a general discussion of the results and findings of this thesis and an explanation of their implications on future IABP research, catheter design and therapy are discussed in Chapter 8. 

Samenvatting 

Dit proefschrift onderzoekt de effecten van de intra-aortale ballonpomp (IABP) op de viscerale bloedvoorziening. IABP is een invasieve mechanische ondersteuningsmodaliteit, welke reeds decennia gebruikt wordt in de klinische praktijk. Net als iedere invasieve mechanische ondersteuningsmodaliteit is het gebruik van deze techniek geassocieerd met serieuze complicaties. Één van deze complicaties betreft het ontwikkelen van viscerale ischemie ten gevolge van obstructieve, maar ook non-obstructieve plaatsing van de IABPkatheter. In dit proefschrift gaan we dieper in op de viscerale effecten van optimaal geplaatste (non-obstructieve) IABP-katheters. Daarnaast wordt besproken welke optimalisaties in het gebruik van deze ondersteuningsmodaliteit doorgevoerd kunnen worden om dit complicatierisico te beperken.

IABP-therapie wordt reeds decennia gebruikt om patiënten met een cardiogene shock tijdelijk te ondersteunen middels een ballonkatheter. Deze wordt meestal ingebracht via één van de femoralis arteriën in de aorta descendens, net $2 \mathrm{~cm}$ onder de linker arteria subclavia. Indien deze katheter is ingebracht zal deze ervoor zorgen dat de coronaire perfusie verbetert gedurende diastole door het gesynchroniseerd opblazen van de ballon op deze katheter. In deze kritieke periode van cardiogene shock wordt zo de perfusie van de coronairen verbeterd. Daarnaast zorgt deze techniek ervoor dat de weerstand waartegen het hard moet pompen ('afterload') verminderd wordt ten tijde van systole, door het snelle leeglaten van dezelfde ballon.

Een algemene uitleg over de fysiologische achtergrond van IABP-ondersteuning, indicaties, contra-indicaties en viscerale complicaties tezamen met de doelstellingen voor dit proefschrift wordt gegeven in hoofdstuk 1.

In hoofdstuk 2 gaan we in op de 'golfpatronen' (i.e. 'wave patterns') in de arteria mesenterica superior (AMS) en de beide nier-arteriën. In proefdieronderzoek laten we zien dat deze 'wave patterns' in de AMS meer worden aangedaan dan die van de nierarteriën. Derhalve is er mogelijk ruimte voor een hernieuwde discussie van het gebruik en ontwikkelen van gesegmenteerde IABP-katheters om deze interferentie met de viscerale perfusie te verminderen.

In hoofdstuk 3 verkrijgen we meer inzicht in de werking van IABP door het variëren van de ballonvolumina in het geleidelijke afbouwen van deze ondersteuning ('weaning'). Algemeen genomen kan er middels een geleidelijke afbouw van volume van de ballon op de katheter, danwel geleidelijke aanpassing van de ondersteuningsratio (van 1:1; naar 1:2 etc.) IABP-ondersteuning worden afgebouwd. In deze proefdierstudie laten wij dus zien dat een geleidelijke afbouw van het ballonvolume tijdens het 'weaningsproces' leidt tot een verbeterde hemodynamiek, coronaire circulatie en metabool profiel.

Obstructieve malpositie van een IABP-katheter kan logischerwijs leiden tot perfusiestoornissen van één, dan wel meerdere viscerale arteriën. Echter, zelfs indien implanteurs zich strikt houden aan implantatieprotocollen van fabrikanten ziet men veelvuldig problemen ten gevolge van een zogeheten 'mismatch' tussen ballonkatheter 
en de heersende individuele anatomie. Het gebruik van kortere ballonnen op de katheters zou mogelijk verbetering kunnen bieden.

In hoofdstuk 4 tot $\mathbf{7}$ gaan we in op het gebruik van korte en langere (conventionele) IABPkatheters met diverse volumina (Zeon Medical Inc., Tokyo, Japan), in een proefdiermodel van ischemie-reperfusie. Zo worden een conventionele $40-\mathrm{mL}$ en $35-\mathrm{mL}$ katheter vergeleken met twee innovatieve kortere katheters: een $40-\mathrm{mL}$ en een prototype $35-\mathrm{mL}$ katheter. Hierbij bestuderen we de effecten op de viscerale circulatie, hemodynamiek en de coronaire circulatie en metabolisme.

In hoofdstuk 4 wordt een zogeheten 'proof-of-principle' studie beschreven, waarbij ondersteuning middels IABP middels de twee korte katheters (35-mL (prototype) en 40$\mathrm{mL}$ ) wordt vergeleken met een controlegroep. Na 2 uur ischemie bleek er sprake van evidente verslechtering van de hemodynamiek, viscerale en coronaire circulatie in alle groepen. Tijdens de reperfusie leidde het gebruik van IABP middels de genoemde katheters tot een verbetering van zowel de doorbloeding van AMS, nier-arteriën, coronairen als ook een verbetering van de hemodynamiek in vergelijking met de niet ondersteunde controlegroep. IABP-ondersteuning middels deze kortere ballonkatheters ging dus gepaard met klassieke effecten van IABP gebruik: evidente verbetering van de hemodynamiek en coronaire circulatie, maar bleek daarnaast ook gunstig voor de viscerale circulatie. Derhalve raakten wij benieuwd naar de effecten van IABPondersteuning van deze kortere katheters.

Volgend op de vragen opgeworpen in hoofdstuk 4 worden er in hoofdstuk 5 twee (één korte en één lange) identieke volume ( $40 \mathrm{~mL}$ ) IABP-katheters met elkaar vergeleken in de eenzelfde setting van ischemie-reperfusie. De effecten op de hemodynamiek, coronaire circulatie en metabolisme bleken bij beide katheters gelijk. Desondanks, ondanks adequate plaatsing van de katheters bleek de doorbloeding in de AMS enkel te verbeteren in de kortere 40-mL ballonvariant, terwijl de langere ballon juist een negatieve invloed had op de AMS-doorbloeding. Deze effecten van de kortere katheter bleven bestaan wanneer werd geïndexeerd voor gemiddelde bloeddruk, systemische vaatweerstand en 'cardiac output'. Voor de doorbloeding van de nier-arteriën bleek het gebruik van beide katheters bevorderlijk, maar waren de effecten van het gebruik van de korte katheters significant gunstiger dan die van langere katheters. Mogelijk leid het gebruik van kortere katheters tot een meer laminaire bloedstroom ter hoogte van de AMS en de nier-arteriën wat deze resultaten zou kunnen verklaren. De resultaten uit deze studie hebben mogelijk directe implicaties voor de kliniek: het gebruik van kortere katheters kan mogelijk leiden tot een verbetering van de viscerale doorbloeding, zonder daarbij compromissen te sluiten ten aanzien van de reguliere effecten van ondersteuning middels IABP.

Hoofdstuk 6 beslaat een proefdierstudie, waarin de prototype 35-mL IABP-katheter wordt vergeleken met de conventionele (langere) 40-mL IABP-katheter. Mogelijk zou deze 
kleinst beschikbare katheter, met in theorie de minste effecten op de viscerale circulatie, het gebruik van reguliere (langere) katheters vandaag de dag kunnen vervangen. In de reperfusie-fase leidde het gebruik van de prototype $35-\mathrm{mL}$ katheter tot een significante verbetering van de bloedvoorziening van de AMS, waarbij de conventionele 40-mL katheter juist leidde tot een daling van deze bloedstroom. Toepassing van IABP-therapie middels beide katheters leidde daarnaast tot een verbetering van de renale circulatie, alhoewel dit bij het gebruik van de prototype 35-mL katheter significant meer was ten opzichte van de conventioneel gebruikte 40-mL katheter. De verbeterde viscerale doorbloeding van de $35-\mathrm{mL}$ prototype katheter ging desondanks niet ten koste van de 'klassieke' effecten van IABP-therapie. Het gebruik van de prototype 35-mL katheter leidde daarnaast tot dezelfde hemodynamische, dan wel coronaire effecten zoals ook gezien werd bij het gebruik van de reguliere, langere, 40-mL katheter.

Aangezien hoofdstuk 6 ons leerde dat het gebruik van de prototype $35-\mathrm{mL}$ IAB in vergelijking met de conventioneel gebruikte langere 40-mL katheter, gepaard ging met significante viscerale voordelen, zonder daarbij de klassieke hemodynamische en coronaire effecten teniet te doen, rees bij ons de vraag in hoeverre de reeds beschikbare 35-mL katheter eenzelfde profiel zou laten zien. Deze 35-mL 'lange' IAB-katheter komt met een substantieel kortere ballon in vergelijking met zijn 40-mL equivalent $(214 \mathrm{~mm}$ vs. $243 \mathrm{~mm})$, maar heeft daarnaast eenzelfde diameter $(15.1 \mathrm{~mL})$. Ter vergelijk: de kortere 40-mL en prototype 35-mL zijn nog korter met een minimaal toegenomen diameter (173/ 17,5 mm vs. 162/17,1mm). In hoofdstuk 7 vergelijken we derhalve de reeds beschikbare 35-mL 'lange' IABP-katheter met de drie eerdergenoemde alternatieven.

Alle geteste katheters lieten in dit hoofdstuk eenzelfde hemodynamische en coronaire effecten zien. Ondanks het feit dat de 'lange' 35- $\mathrm{mL}$ katheter $29 \mathrm{~mm}$ korter is dan de 40$\mathrm{mL}$ 'lange' variant, ging het gebruik van deze katheter gepaard met eenzelfde negatieve effect op de doorbloeding van de AMS in vergelijking met de twee 'kortere' katheters. Het gebruik van beide 'langere' katheters leidde tot een gelijkwaardige verbeterde perfusie van beide nier-arteriën, maar in vergelijking met de twee 'kortere' IABPkatheters bleek dit significant minder. Derhalve impliceren deze bevindingen dat veranderingen in de viscerale circulatie ten tijde van IABP-ondersteuning eerder gerelateerd zijn aan katheter-ballon lengte en niet aan een kleine toename $(5 \mathrm{cc})$ in ballon volume.

Uiteindelijk eindigt dit proefschrift met een algemene discussie, waarbij de resultaten en implicaties hiervan op toekomstig onderzoek, katheter ontwikkeling en behandeling worden besproken in hoofdstuk 8 . 